Protocols

\title{
Encapsulation of living bacteria in electrospun cyclodextrin ultrathin fibers for bioremediation of heavy metals and reactive dye from wastewater
}

\author{
Nalan Oya San Keskin a,b,c,**, Asli Celebioglu ${ }^{\mathrm{a}, \mathrm{d}}$, Omer Faruk Sarioglu ${ }^{\mathrm{a}, \mathrm{d}}$, Tamer Uyar ${ }^{\mathrm{a}, \mathrm{d}, *}$, \\ Turgay Tekinay ${ }^{c, e, * *}$ \\ a UNAM-National Nanotechnology Research Center, Bilkent University, Ankara 06800, Turkey \\ b Polath Science and Literature Faculty, Biology Department, Gazi University, Ankara 06900, Turkey \\ ${ }^{\mathrm{c}}$ Life Sciences Application and Research Center, Gazi University, Ankara 06830, Turkey \\ ${ }^{\mathrm{d}}$ Institute of Materials Science and Nanotechnology, Bilkent University, 06800 Ankara, Turkey \\ e Faculty of Medicine, Department of Medical Biology and Genetics, Gazi University, Ankara 06560, Turkey
}

\section{A R T I C L E I N F O}

\section{Article history:}

Received 23 February 2017

Received in revised form 11 October 2017

Accepted 17 October 2017

Available online 18 October 2017

\section{Keywords:}

Electrospinning

Cyclodextrin

Nanofibers

Bacteria

Encapsulation

Heavy metals

Reactive dye

\begin{abstract}
A B S T R A C T
Cyclodextrins (CD) are cyclic oligosaccharides produced from the enzymatic degradation of starch as a white powder form; on the other hand, they can be transformed into ultrathin electrospun fiber form by electrospinning technique. The electrospun cyclodextrin fibers (CD-F) can be quite attractive materials to encapsulate bacteria for bioremediation purposes. For instance, $C D-F$ not only serve as a carrier matrix but also it serves as a feeding source for the encapsulated bacteria. In the present study, we demonstrate a facile approach by encapsulation of bacteria into CD-F matrix for wastewater treatment application. The natural and non-toxic properties of CD-F render a better bacterial viability for fibrous biocomposite. The encapsulated bacteria in CD-F exhibit cell viability for more than 7 days at $4{ }^{\circ} \mathrm{C}$ storage condition. Furthermore, we have tested the bioremediation capability of bacteria/CD-F biocomposite for the treatment of heavy metals (Nickel(II) and Chromium(VI)) and textile dye (Reactive Black 5, RB5). The bacteria/CD-F biocomposite has shown removal efficiency of $\mathrm{Ni}(\mathrm{II}), \mathrm{Cr}(\mathrm{VI})$ and $\mathrm{RB} 5$ as $70 \pm 0.2 \%, 58 \pm 1.4 \%$ and $82 \pm 0.8$, respectively. As anticipated, the pollutants removal capabilities of the bacteria/CD-F was higher compare to free bacteria since bacteria can use $C D$ as an extra carbon source which promotes their growth rate. This study demonstrates that $\mathrm{CD}-\mathrm{F}$ are suitable platforms for the encapsulation of bacterial cells to develop novel biocomposites that have bioremediation capabilities for wastewater treatment.
\end{abstract}

(c) 2017 Elsevier B.V. All rights reserved.

\section{Introduction}

The use of biomass such as bacteria, fungi and algae as a biosorbent have great potentials for cleaning up environmental contaminants due to the availability of wide range of sorption sites which retain metals and metallic ions, as well as other organic compounds [1,2]. A variety of approaches are employed in bioremediation, encapsulation of bacterial cells is considered to be the most promising due to their potential in removing specific contaminants within a carrier matrix [3]. Encapsulation has many promising

\footnotetext{
* Corresponding author at: UNAM-National Nanotechnology Research Center, Bilkent University, Ankara, 06800, Turkey.

** Corresponding authors at: Polatlı Science and Literature Faculty, Biology Department, Gazi University, Ankara, 06900, Turkey.

E-mail addresses: oyasan@gazi.edu.tr (N.O. San Keskin), uyar@unam.bilkent.edu.tr (T. Uyar), ttekinay@gazi.edu.tr (T. Tekinay).
}

applications in a broad range of fields from bioreactors to medicine. Advantages of encapsulated cells include, ease of separation, protection from harsh external conditions, and reduced susceptibility to contamination by foreign organisms. The most common encapsulation techniques are spray-drying [4], emulsifying-crosslinking [5] or coacervation [6]. However, these techniques involve use of high temperature or organic agents in at least one of the production steps, leading to potential destruction of sensitive encapsulated nutrients as well as toxicity problems associated with residual organic agents [7]. Hence, to overcome these limitations, new encapsulation technologies that do not involve harsh conditions such high temperature and toxic solvents are being investigated, which can provide effective encapsulation for sensitive guest agents.

Recently, electrospinning technique has attracted certain attention in which active agents such as pharmaceuticals [8,9], food additives [10-12] are being simultaneously encapsulated into fiber matrix via electrospinning process. Electrospun fibers have 
received a great deal of attention owing to their high surface area, very light-weight, nano-porous nature, and flexibility in specific physical and chemical functionalization [13-15]. Thereby, electrospun fibers and their webs are very promising candidates for membranes/filters and environmental applications [16-20]. For example, electrospun webs were also used as immobilization matrix for living microorganism for remediation of waste water [21-24]. There are also very few reports about encapsulation of microorganism in electrospun fibers. For example, Salalha et al. [25] showed encapsulation of Escherichia coli and Staphylococcus albus by electrospinning of bacteria suspensions with polyvinyl alcohol (PVA). Further, Fung et al. [26] has successfully encapsulated probiotics in agrowaste-based nanofibers, and Liu et al. [27] has fabricated an insoluble fibrous material via electrospinning which encapsulate industrially important bacteria. Another report by Vajdai et al. [28] demonstrates successful tracking of cell viability of Stenotrophomonas maltophilia bacteria in PVA fibrous webs. Furthermore, Lee and Belcher fabricated one-dimensional (1D) micro- and nanosized diameter fibers with long rod-shaped M13 viruses [29]. Encapsulation technique may represent excellent alternative to lyophilization for the preservation of organisms. Furthermore, no need to wait bacterial attachment (3-21 days) and has lower contamination risk. Even though few studies reported successful encapsulation of bacteria in electrospun matrix, the proof-of-concept studies for the potential applications of these fibers have not been demonstrated satisfactorily. One of our recent study bioremediating bacterial cells were successfully encapsulated into polyvinyl alcohol (PVA) and polyethylene oxide (PEO) polymeric matrices while keeping the bacteria bioactive and the viable cell numbers in desirable amounts [30]. Moreover, the choice of fiber matrix was often a water soluble polymer such as PVA or PEO since aqueous solution was preferably used as an electrospinning solution in order to provide suitable environment for the bacteria before electrospinning. Yet, after the electrospinning, these synthetic polymeric matrixes are not very appropriate once the bacteria are encapsulated within the matrix since bacteria need carbon source for their survival. Hence, carbohydrate-based fiber would be much preferable matrix for the encapsulation of bacteria. Therefore, in this study we choose cyclodextrin (CD) electrospun fiber matrix to encapsulate bacteria for bioremediation purposes. CDs are classified as cyclic oligosaccharides which are produced from starch as a white powder form, and they can be transformed into fiber form by electrospinning technique [31-34]. In general, polymeric materials are needed for the electrospinning of fibers since chain entanglement and overlapping between the polymer chains are the requirements to sustain the continuous jet elongation during the electrospinning process $[13,14]$. Nevertheless, in our recent studies we have shown successful electrospinning of fibers from $\mathrm{CD}$ without using any polymeric carrier matrix. Although $\mathrm{CD}$ are cyclic oligosaccharides, which are considered to be very small molecules compared to polymers, the self-assembly and aggregation characteristics of CD molecules in their concentrated solutions enables the electrospinning of fibers from $C D$ without the need of carrier polymeric matrix [31-34].

In our study, we successfully demonstrated the encapsulation of Lysinibacillus sp. NOSK bacteria in water based and biocompatible non-polymeric cyclodextrin fibers (CD-F) using electrospinning process. The CD-F protects bacterial cells to reduce the effects of exterior environment; beside they served as an encapsulating matrix and carbon-source for the bacteria. Furthermore, these bacteria encapsulated water-soluble fibers exhibited an instant release mechanism. The potential application of this bacteria/CD-F biocomposite in bioremediation of heavy metals ( $\mathrm{Ni}(\mathrm{II})$ and $\mathrm{Cr}(\mathrm{VI})$ ions) and reactive dye from aqueous solution was systematically investigated. The morphological characteristics of the pristine and bacteria encapsulated fibers were evaluated. Our results clearly

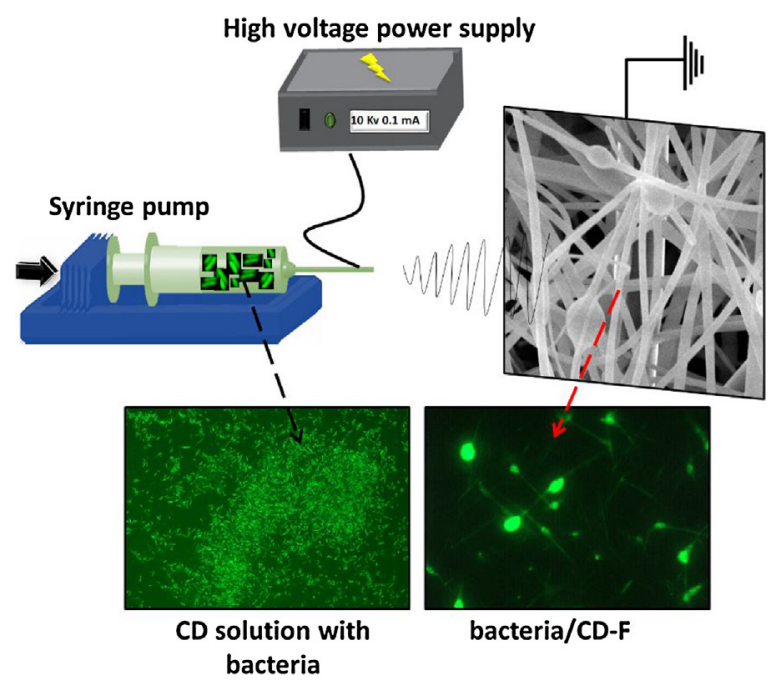

Fig. 1. Schematic view of encapsulation of bacteria in electrospun fibers by electrospinning process (CD: Cyclodextrin, F: Fiber).

showed that encapsulated Lysinibacillus sp. NOSK were viable, and their metabolic activity was not affected by the encapsulation into electrospun CD-F. On the basis of present results, we can suggest that this novel bacteria/CD-F biocomposite could be of interest for wastewater treatment.

\section{Material and methods}

\subsection{Materials}

The hydroxypropyl- $\beta$-cyclodextrin (HP $\beta C D$ ) (degree of substitution: $\sim 0.6$, Cavasol ${ }^{\circledR}$ W7 HP Pharma) was kindly donated by Wacker Chemie AG (Germany). The deionized water was obtained from the Millipore Milli-Q Ultrapure Water System. The stock solution of $\mathrm{Ni}(\mathrm{II})$ was prepared by dissolving nickel sulfate heptahydrate (Sigma Aldrich, 99.9\%) in deionized water. Potassium dichromate (Sigma Aldrich, $\geq 99.0 \%$ ) was used to prepare $\mathrm{Cr}(\mathrm{VI})$ aqueous solution by dissolving in deionized water. Reactive dye (Reactive Black 5 (RB5)) was obtained from SETAŞ Chemistry Factory (Tekirdag, Turkey). Appropriate volume of the stock solutions was added to the nutrient broth (NB) medium (Peptone from meat $5.0 \mathrm{~g} / \mathrm{L}$; Meat extract $3.0 \mathrm{~g} / \mathrm{L}$ ) for preparation of the experimental samples.

\subsection{Cultivation of bacterium in nutrient broth (NB)}

The Lysinibacillus sp. NOSK culture isolated from wastewater treatment system [35] was routinely maintained in Nutrient Broth (NB) medium. The working bacterial culture was prepared from the stock culture stored at $-20{ }^{\circ} \mathrm{C}$ in $70 \%(\mathrm{v} / \mathrm{v})$ sterile glycerol. The frozen stock cultures were revived three times in NB medium prior to experimental use. There activated culture was grown in Erlenmeyer flasks containing NB medium to get enough active inoculum. The freshly cultured cells were collected by centrifugation at $5000 \mathrm{rpm}$ for $10 \mathrm{~min}$ and then defined volume of biomass used for electrospinning process.

\subsection{Electrospinning of bacteria encapsulated cyclodextrin fibers (bacteria/CD-F) and bacteria-free $C D-F$}

The electrospinning of bacteria encapsulated CD-F were performed by using highly concentrated aqueous CD solution $(200 \%$, $\mathrm{w} / \mathrm{v}$ ) with $0.5 \%(\mathrm{w} / \mathrm{v})$ of skim milk media (Fig. 1). For bacteria encapsulation process, electrospinning was carried out by making 
a suspension of bacteria in the $\mathrm{CD}$ aqueous solution. The amount of bacteria in the $\mathrm{CD}$ aqueous solution was varied as $0.25 \%, 0.5 \%$, $1 \%$ and $2 \%(\mathrm{w} / \mathrm{w})$ (respect to $\mathrm{CD}$ concentration) in order to get enough bacterial count in CD-F. The electrospinning of bacteria-free CD solution and bacteria/CD suspension were performed separately by using $1 \mathrm{~mL}$ syringe with a needle of an inner diameter of $0.4 \mathrm{~mm}$. One of the electrodes of the high voltage power supply (Matsusada Precision, AU Series) was clamped to the metal needle tip, and the other was clamped to the grounded cylindrical aluminum collector. The electrospinning parameters were optimized as follows: applied voltage: $15 \mathrm{kV}$, tip-to-collector distance: $10 \mathrm{~cm}$, and the solution flow rate: $0.5 \mathrm{~mL} / \mathrm{h}$. All the electrospinning processes were performed in a UV sterile electrospinning cabin at room temperature $\left(\sim 24^{\circ} \mathrm{C}\right)$ and $25 \%$ relative humidity conditions. After electrospinning process, the bacteria encapsulated $\mathrm{CD}$ fibers have been stored at $4{ }^{\circ} \mathrm{C}$ (in a refrigerator) in small plastic petri dishes which were enclosed by paraffin bands for prevention of air and humidity passage. Petri dishes were sterile (UV-sterilized), dry and having minimized headspace volume (by overspread with bacteria $\mathrm{CD}-\mathrm{F}$ ) to enhance the stability of the encapsulated bacteria.

\subsection{Viability testing}

In order to check bacterial viability and their successful encapsulation within the electrospun CD-F, Lysinibacillus sp. NOSK cells were stained with fluorescent stains (LIVE/DEAD BacLightTM kit) prior to the electrospinning process. Microscopic assessment of LIVE/DEAD-stained bacterial cells is usually simplified with "green"-labeled cells for alive bacteria. Photographs were taken by using an optical microscope with an attached fluorescence unit (Leica, DMI 4000 B). The viability of Lysinibacillus sp. NOSK either in electrospinning solutions or encapsulated in CD-F was also determined as colony-forming units (CFU) using the pour-plate assay. To evaluate the encapsulation efficiency, pieces of the CD-F fibrous material were weighed $(10 \mathrm{mg})$ which contain the living organisms. Nutrient medium $(1.0 \mathrm{~mL})$ was added to these pieces in microcentrifuge tubes, held for $60 \mathrm{~min}$ at room temperature and serial 10 -fold dilutions were made on these samples and plated on Nutrient agar. After incubation at optimal conditions, the number of CFU was determined. All tests were performed in triplicate.

\subsection{Characterization}

The morphological investigation of the fibers was carried out by using scanning electron microscopy (SEM) (200 FEG, FEI). The samples were sputter coated (PECS-682) with a gold-palladium alloy for $\sim 5 \mathrm{~nm}$ thickness prior to SEM imaging.

Raman spectra of the samples were recorded on a WITec alpha300S Confocal Raman spectrometer. The near-infrared $785 \mathrm{~nm}$ line was used for excitation. For all presented spectra, the laser power on the sample did not exceed $3 \mathrm{~mW}$, and 10 scans were collected in $15 \mathrm{~s}$. All spectra were recorded with a spectral resolution of $4 \mathrm{~cm}^{-1}$.

\subsection{Removal analysis}

During the incubation period, a $3 \mathrm{~mL}$ sample was taken daily from each flask. Samples were centrifuged to precipitate suspended biomass at $10.000 \mathrm{~g}$ for $5 \mathrm{~min}$. Cell free nutrient broth medium was used as the blank. The concentrations of $\mathrm{Ni}(\mathrm{II})$ in the supernatant was determined spectrophotometrically at $340 \mathrm{~nm}$ by using sodium diethyl dithiocarbamate (from Merck) as a complexing agent. Residual $\mathrm{Cr}(\mathrm{VI})$ in the supernatant was measured using the 1,5-diphenylcarbazide (from Alfa Aesar, A Johnson Mathey Company, USA) method at $540 \mathrm{~nm}$ by UV spectrophotometer. The concentration of dye (RB5) in each aqueous solution was measured on an UV-vis spectrophotometer while taking the absorption at $597 \mathrm{~nm}$. All tests were performed in triplicate.

\subsection{Adsorption isotherms and kinetics studies}

Adsorption coefficients were estimated via seven isotherm models (Langmuir, Langmuir with linear partitioning, Freundlich, Freundlich with linear partitioning, Generalized Langmuir-Freundlich, Toth, Linear) using the isotherm parameter fitting software IsoFit [35]. The mean of three individual determinations was used to calculate cell counts.

\section{Results and discussion}

\subsection{Electrospinning of bacteria encapsulated cyclodextrin fibers (bacteria/CD-F) and bacteria-free $C D-F$}

The electrospinning of pure CD-F without containing bacteria was performed to obtain control sample. The representative SEM images of electrospun bacteria-free CD-F are shown in Fig. S1a-b. The average fiber diameter of the electrospun CD-F was calculated as $605 \pm 205 \mathrm{~nm}$ by measuring about 100 fibers from different SEM images. In order to achieve continuous fiber production by electrospinning, one of the important optimization parameter is finding the optimal bacteria amount for encapsulation process. Regard to this, the optimization of bacteria amount for encapsulation in $C D$ fibers was investigated by using $0.25 \%, 0.5 \%, 1 \%$ and $2 \%(\mathrm{w} / \mathrm{w}$ ) of bacteria and the morphologies of the fibers' structures were analyzed by SEM.

SEM micrograph of the bacterium is shown in Fig. S2. In Fig. 2, SEM imaging confirmed the successful electrospinning of $C D$ aqueous solution into bead-free and uniform fibers having smooth morphology. The incorporation of Lysinibacillus sp. NOSK into CD solution did not significantly affect the electrospinning process and in all bacteria concentration used, fibers were successfully produced (Fig. 2a-d). However, we had some difficulties for the electrospinning of $\mathrm{CD}$ solution containing $2 \%(\mathrm{w} / \mathrm{w})$ of bacteria, the electrospinning jet was disturbed frequently (Fig. 2d). Therefore, we decided that $1 \%(\mathrm{w} / \mathrm{w})$ of bacteria was an optimal concentration for the continuous electrospinning of bacteria/CD-F to obtain homogenously distributed fibrous webs (Fig. 2c). In a closer look, the bacterial cells were completely encapsulated within the $C D$ fiber matrix, forming local widening of the fiber. Enlargement and widening of some regions in the fibers for the bacteria/CD-F samples was preliminary evidence for bacterial incorporation inside the CD-F as depicted in Fig. 2a-d. From Fig. 2a thru Fig. 2d, it was also evident that when bacterial number was increased in the electrospinning solution, the encapsulated cell number was increased as well in the electrospun CD-F matrix.

\subsection{Viability}

Viability of Lysinibacillus sp. NOSK cells was determined as number of colony-forming units (CFU) in CD solution and in CD-F web at refrigeration temperature $\left(4^{\circ} \mathrm{C}\right)$ at different time intervals $(24 \mathrm{~h}$ to 7 days) (Fig. 3). Over a period of time, bacterial cell viability was decreased, only a significant percentage of bacteria retained their viability at the end of 7 days. The cell viability of Lysinibacillus sp. NOSK was found to be $2.5 \times 10^{3} \mathrm{CFU} / \mathrm{mL}$ in $\mathrm{CD}$ solution prior to encapsulation, which was decreased to $6.0 \times 10^{2} \mathrm{CFU} / \mathrm{mL}$ in bacteria/CD-F stored at $4{ }^{\circ} \mathrm{C}$ on day 1 . The bacterial cell was further decreased to $3.0 \times 10^{2} \mathrm{CFU} / \mathrm{mL}$ upon the bacteria/CD-Fs storage at $4{ }^{\circ} \mathrm{C}$ for 7 days. Further, fluorescence staining technique was performed in order to get an accurate cell viability assessment and cell count. The loss in cell viability could be attributed to the effect of electrostatic field generated during the electrospinning process 

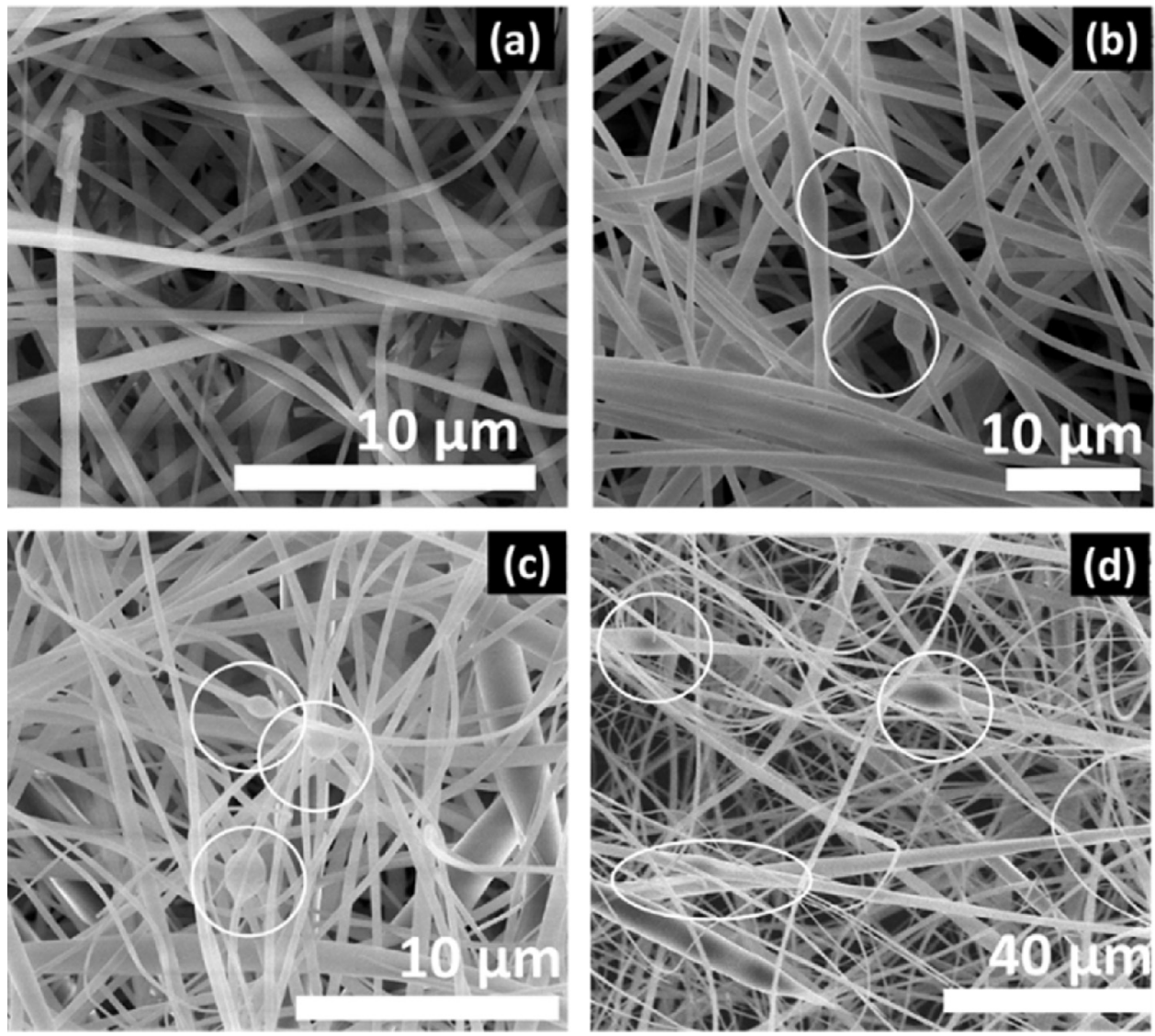

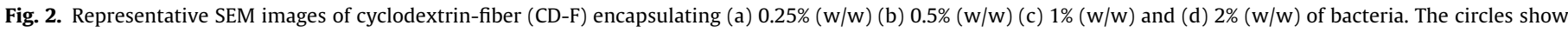
some of the encapsulated bacterium into the electrospun fiber matrix.

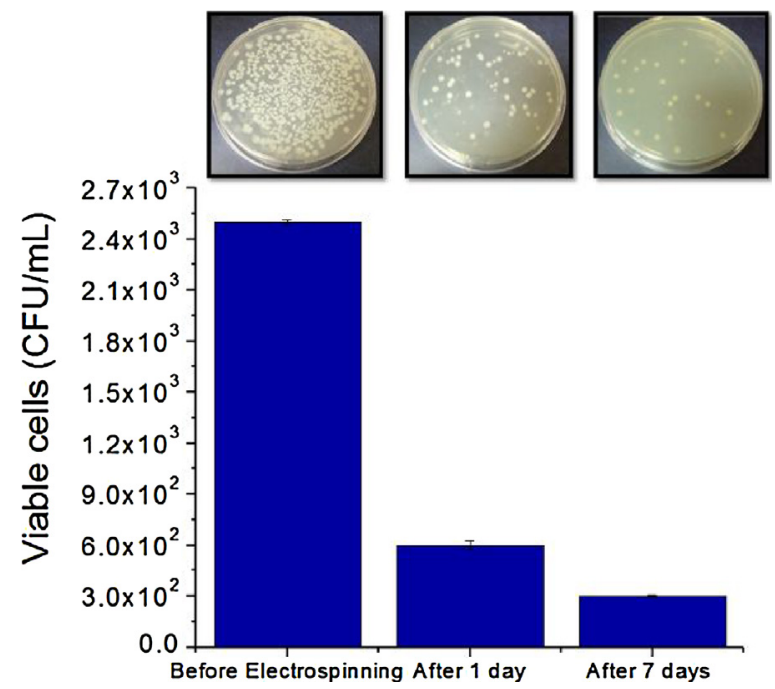

Fig. 3. Viability of Lysinibacillus sp. NOSK as number of colony-forming units (CFU) in $\mathrm{CD}$ solution and bacteria/CD-F at $4{ }^{\circ} \mathrm{C}$ and different storage times (1 day to 7 days). Inset photographs shows bacteria count on the agar surface.

due to the application of high voltage between the metal capillary and the collector $[8,9]$. Furthermore, rapid evaporation of water during electrospinning process is also anticipated to cause drastic changes in the osmotic environment of the bacteria. The effect of storage on the viability of encapsulated bacteria is of great concern for their potential application in industrial-scale processes, since application of these novel bioactive biocomposites requires to be intact and functional at the time of use in desired site.

\subsection{Characterization}

In addition to the SEM image, presence of Lysinibacillus sp. NOSK was further supported by fluorescence microscopy images. Fig. 4a clearly indicates that the stained Lysinibacillus sp. NOSK bacterial cells emit green fluorescence owing to their viability nature which confirms their successful encapsulation in CD-F matrix (Fig. 4b). Although bacterial cells were generally localized individually inside the fiber matrix, some more agglomerated cells were also observed in certain areas of the fibrous web.

Raman spectroscopy is considered to be an molecular fingerprinting technique for studying structure of polymers and microorganisms [36]. Raman spectra of pristine CD-F, pristine bacteria and bacteria/CD-F with main Raman shifts and assignments of the Raman bands are given in Fig. 5. The observed peaks around $851 \mathrm{~cm}^{-1}$ in the Raman spectrum of pristine CD-F is due to skeletal $\mathrm{CCH}$. Pristine bacteria Raman spectra shows the amide I vibration at $1650 \mathrm{~cm}^{-1}$, and the $\mathrm{CH}_{2}$ deformation vibration at $1420 \mathrm{~cm}^{-1}$. After encapsulation process, presence of proteins in the bacteria/CD-F was confirmed from the peak around $1005 \mathrm{~cm}^{-1}$ and as well two prominent peaks i.e., $\sim 1048$ and $\sim 995 \mathrm{~cm}^{-1}$ observed at polysaccharide region (1200-900 $\mathrm{cm}^{-1}$ ) could be arising from vibrations in the peptidoglycan of bacterial cell wall ${ }^{26}$ which further confirmed the presence of the bacterial cells in the fibrous matrix.

\subsection{Removal analysis}

The heavy metal removal capability of the bacteria/CD-F was investigated in a batch system with regard to the initial $\mathrm{pH}$ and $\mathrm{Ni}(\mathrm{II})$ concentrations. Uninoculated erlenmeyer flasks containing heavy metals, reactive dye and CD-F were used as control sam- 

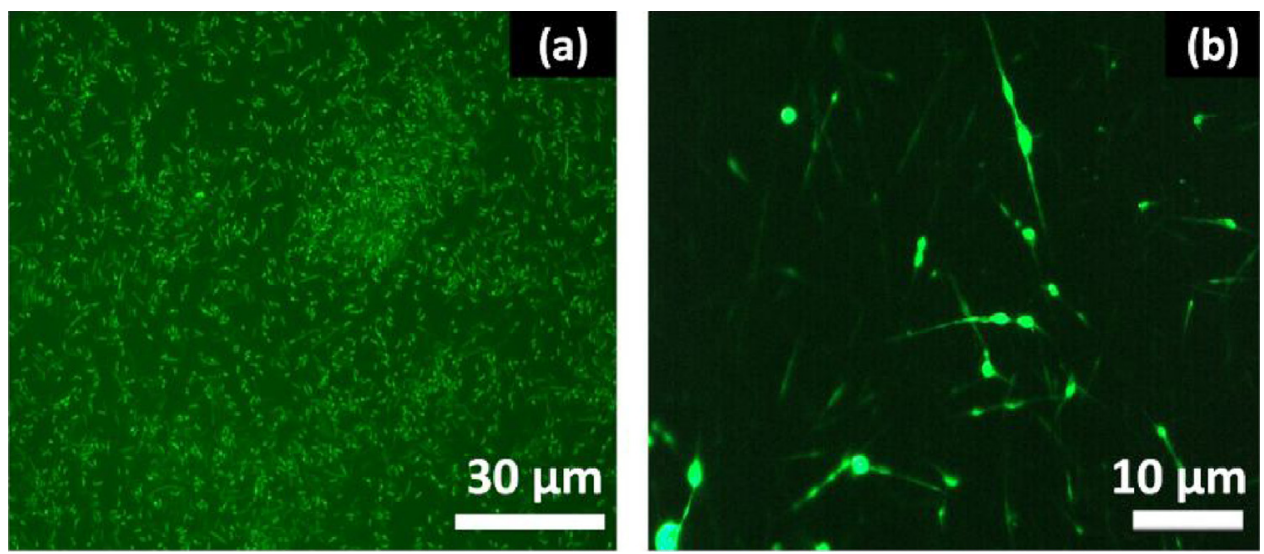

Fig. 4. Fluorescence microscopy images of bacteria (a) before encapsulation process (b) after encapsulation in CD-F matrix.

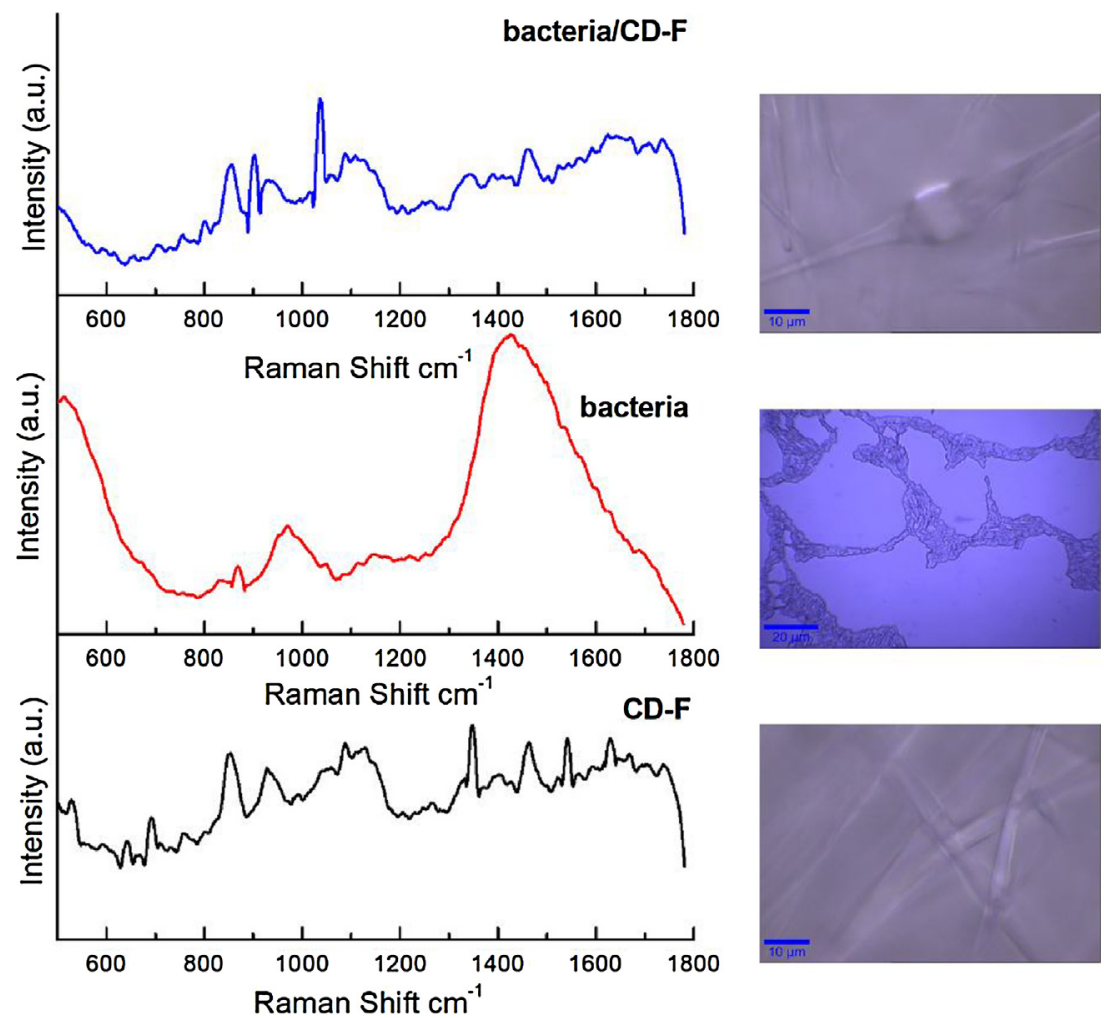

Fig. 5. Raman spectra of (a) pristine CD-F (b) pristine bacteria and (b) bacteria/CD-F. Insets show the micrograph of pristine $C D-F$, pristine bacteria and bacteria/CD-F.

ples to observe any reactions of the media with heavy metal and dye (Fig. S3). In these samples, removal yield was $0.8 \%$ for $\mathrm{Ni}(\mathrm{II})$, $0.3 \%$ for $\mathrm{Cr}(\mathrm{VI})$ and $\% 0.5$ for RB5. There was no significant difference in the bioremoval yield of $\mathrm{Ni}(\mathrm{II}), \mathrm{Cr}(\mathrm{VI})$ and RB5 by pristine $\mathrm{CD}-\mathrm{F}$, respectively.

The percentage uptake of heavy metals and reactive dye were calculated from the difference between the initial and final values using Eq. (A.1)

$\operatorname{Removal}(\%)=\left(\mathrm{C}_{0}-\mathrm{C}_{\mathrm{eq}}\right) / \mathrm{C}_{0} \times 100$

Here $C_{0}$ and $C_{e q}$ are the initial and equilibrium concentrations of heavy metals and reactive dye $\left(\mathrm{mg} \mathrm{L}^{-1}\right)$, respectively. The removal capacity can be determined by the mass balance principle (Eq. (A.2)).

$\mathrm{q}_{\mathrm{m}}=\left(\mathrm{C}_{0}-\mathrm{C}_{\mathrm{f}}\right) / \mathrm{X}_{\mathrm{m}} \times 100$
In these two equations, $\mathrm{q}_{\mathrm{m}}$ (the maximum heavy metal and dye uptake) represents the maximum amount of heavy metal/dye per unit of dry weight of microbial cells $\left(\mathrm{mg} \mathrm{L}^{-1}\right), \mathrm{X}_{\mathrm{m}}$ represents the maximum dried cell mass $\left(\mathrm{g} \mathrm{L}^{-1}\right)$, and $\mathrm{C}_{0}$ and $\mathrm{C}_{\mathrm{f}}$ represent the initial and final concentrations $\left(\mathrm{mg} \mathrm{L}^{-1}\right)$, respectively.

The initial $\mathrm{pH}$ value of the solution is an important parameter to investigate higher removal capacities. The RB5 and $\mathrm{Cr}(\mathrm{VI})$ removal yields of the bacterial cells were similarly high at $\mathrm{pH} 8.0$ as found in our previous study [35]. Furthermore, in this study, the effect of $\mathrm{pH}$ was examined after $24 \mathrm{~h}$ of bacterial incubation for the samples at an initial $\mathrm{Ni}(\mathrm{II})$ concentration of $30 \mathrm{mg} \mathrm{L}^{-1}$, but at different initial $\mathrm{pH}$ values within the range of 4-9. As shown in Fig. 6, the removal efficiencies after $24 \mathrm{~h}$ were found as \%77.0, \%77.5, \%78.0, \%76.1, \%72.1 and \%71.7 at $\mathrm{pH}$ values of 4.0, 5.0, 6.0, 7.0, 8.0 and 9.0, respectively. The optimal $\mathrm{pH}$ range for $\mathrm{Ni}(\mathrm{II})$ removal was found to be 4.0-6.0. A near-neutral pH condition is preferable since opera- 


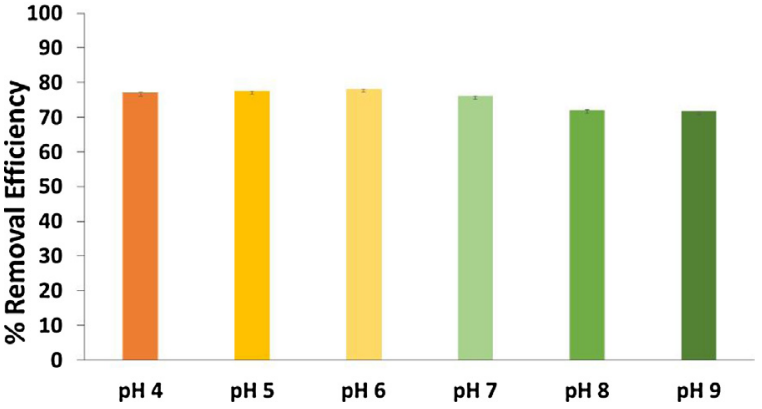

Fig. 6. The effect of $\mathrm{pH}$ on the $\mathrm{Ni}(\mathrm{II})$ removal yield of the free bacteria at $10 \mathrm{mg} \mathrm{L}^{-1}$ of initial $\mathrm{Ni}(\mathrm{II})$ concentration $\left(\mathrm{T}: 30^{\circ} \mathrm{C}\right.$; stirring rate: $\left.100 \mathrm{rpm}\right)$. Error bars represent standard deviation of the mean values for independent replicates $(\mathrm{n}=3)$.

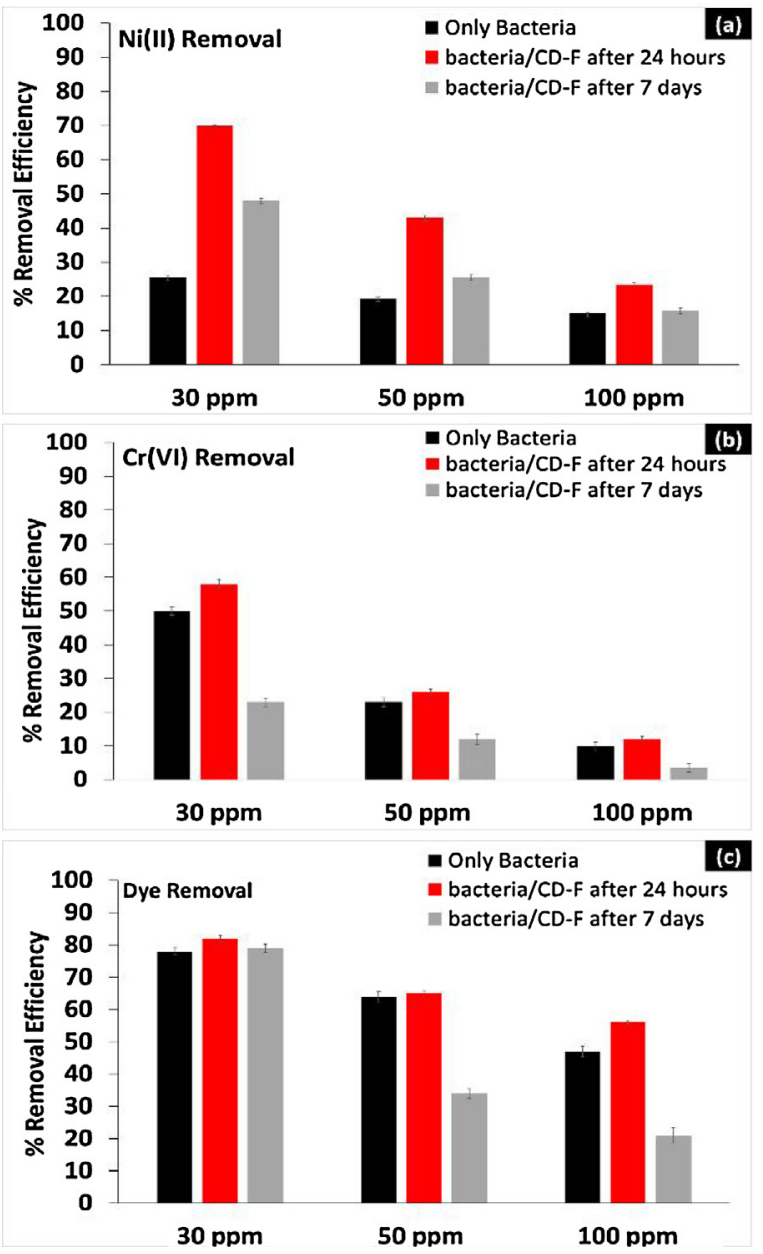

Fig. 7. The effect of initial (a) $\mathrm{Ni}(\mathrm{II})$ (b) $\mathrm{Cr}(\mathrm{VI})$ and (c) Reactive Black 5 concentration on the removal yield of the free bacteria and bacteria/CD-F after 1 day and 7 days storage at $4{ }^{\circ} \mathrm{C}$ during the $24 \mathrm{~h}$ incubation period (T: $30^{\circ} \mathrm{C}$; stirring rate: $100 \mathrm{rpm}$ ). Error bars represent standard deviation of the mean values for independent replicates $(n=3)$.

tion under near-neutral conditions can easily be applied to most wastewater systems [37].

The effect of initial $\mathrm{Ni}(\mathrm{II}), \mathrm{Cr}(\mathrm{VI})$ and RB5 concentrations on the bioremoval performance was evaluated using free-bacteria and bacteria/CD-F after $24 \mathrm{~h}$ storage at $4{ }^{\circ} \mathrm{C}$, and after 7 days storage at $4{ }^{\circ} \mathrm{C}$ at different initial heavy metals and dye concentrations $(30 \mathrm{mg}$ $\mathrm{L}^{-1}$ thru $100 \mathrm{mg} \mathrm{L}^{-1}$ ). As seen in Fig. 7a, the average Ni(II) removal yield was calculated as $25.5 \pm 0.3 \%$ for the free-bacteria. After encapsulation process, the $\mathrm{Ni}(\mathrm{II})$ removal yield of bacteria/CD-F was around $70 \pm 0.2 \%$. After 7 days storage at $4{ }^{\circ} \mathrm{C}, \mathrm{Ni}$ (II) removal yield of bacteria/CD-F reduced to $48.07 \pm 0.4 \%$. The $\mathrm{Ni}(\mathrm{II})$ removal capabilities of the bacteria/CD-F were higher than that of the free-bacteria for all the samples having different initial $\mathrm{Ni}(\mathrm{II})$ concentrations. When CD-F matrix was dissolved in the medium, bacteria used CD as an extra carbon source and achieved an enhanced growth rate $\left(\mathrm{OD}_{600} \mathrm{~nm}: 2.09\right)$. However, since the free bacteria had no extra carbon source, their growth rate was not enhanced $\left(\mathrm{OD}_{600} \mathrm{~nm}: 1.03\right)$ (Fig. S4).

The effect of the initial concentration of $\mathrm{Cr}(\mathrm{VI})$ on the removal of $\mathrm{Cr}(\mathrm{VI})$ is shown in Fig. 7b. Lysinibacillus sp. NOSK could reduce $\mathrm{Cr}(\mathrm{VI})$ $50 \pm 1.2 \%, 23 \pm 1.3 \%$ and $9.8 \pm 1.3 \%$ from the medium contains 30,50 and $100 \mathrm{mg} \mathrm{L}^{-1}$, respectively. After encapsulation process, the maximum removal yields of bacteria/CD-F were $58 \pm 1.4 \%, 26 \pm 0.9 \%$ and $12 \pm 0.7 \%$ for 30,50 and $100 \mathrm{mg} \mathrm{L}^{-1} \mathrm{Cr}(\mathrm{VI})$ concentrations. After 7 days storage at $4{ }^{\circ} \mathrm{C}, \mathrm{Cr}(\mathrm{VI})$ removal yields were decreased to $23 \pm 1.2 \%, 12 \pm 1.6 \%$ and $3.5 \pm 1.2 \%$ for 30,50 and $100 \mathrm{mg} \mathrm{L}^{-1} \mathrm{Cr}(\mathrm{VI})$. It is clear that, after 7 days storage with decrease in bacterial count, the removal performances of bacteria/CD-F decrease.

Fig. 7c illustrates the evolution of the dye removal yield as a function of the initial dye concentration. At the end of the incubation period, the maximum removal yields were $78 \pm 1.1 \%$ at $30 \mathrm{mg} \mathrm{L}^{-1}$. The removal capacities of Lysinibacillus sp. NOSK were found to be ranging between $64 \%$ and $47 \%$ in media with increasing RB5 concentrations. The pattern of the changes in removal efficiency of bacteria/CD-F was found to be quite different. Bacteria/CD-F removed the dye efficiently, in spite of increasing dye concentrations up to $300 \mathrm{mg} \mathrm{L}^{-1}$ level, with the highest yield of $82 \pm 0.8 \%$. Removal efficiency decreased, when the dye concentration increased in all of the other trials performed with bacteria. After 7 days storage, the decolorization of RB5 was $79 \pm 1.2 \%$, $34 \pm 1.5 \%$ and $21 \pm 2.3 \%$ for bacteria/CD-F.

\subsection{Adsorption isotherms and order of reactions}

In order to investigate the adsorption processes of heavy metals and dye on bacteria and bacteria/CD-F, five kinetic models were used. Adsorption kinetics parameters and statistical parameters of all isotherms tested for $\mathrm{Ni}(\mathrm{II})$ removal are listed in Table S1. While bacteria/CD-F fits well for each of the tested model, only bacteria does not fit any of the tested models, hence the estimated adsorption isotherm coefficients of this sample was not discussed. No linear component was found in $\mathrm{Ni}(\mathrm{II})$ removal by bacteria/CD-F after storage at $4{ }^{\circ} \mathrm{C}$ for 1 day and 7 days. Linearity assessments for $\mathrm{Ni}(\mathrm{II})$ were found as non linear in Langmuir and Freundlich models. In addition, $\mathrm{Ry}^{2}$ values of linear isotherms are lower than the $\mathrm{Ry}^{2}$ values of other isotherms. The best fitting model for $\mathrm{Ni}(\mathrm{II})$ removal was Langmuir model for bacteria/CD-F after both 1 day storage at $4{ }^{\circ} \mathrm{C}\left(\mathrm{Ry}^{2} 0.993\right)$ and $7 \mathrm{~d}$ storage at $4{ }^{\circ} \mathrm{C}\left(\mathrm{Ry}^{2} \mathrm{0.924}\right)$. Since the highest correlations observed in Langmuir isotherms, $\mathrm{Ni}(\mathrm{II})$ removal is likely to be monolayeric by bacteria/CD-F. The maximum removal capacities $\left(\mathrm{Q}_{\max }\right.$ ) of bacteria/CD-F after storage for 1 day and 7 days under the Langmuir model were estimated to be $45.95 \mathrm{mg} \mathrm{g}^{-1}$ and $30.95 \mathrm{mg} \mathrm{g}^{-1}$, respectively.

Table S2 shows the adsorption kinetics parameters and statistical parameters of all isotherms tested for $\mathrm{Cr}(\mathrm{VI})$ removal. The Langmuir equation correlates the $\mathrm{Cr}(\mathrm{VI})$ adsorption equilibrium data using bacteria/CD-F both 1 day storage at $4{ }^{\circ} \mathrm{C}\left(\mathrm{Ry}^{2} 0.993\right)$ and 7 day storage at $4{ }^{\circ} \mathrm{C}\left(\mathrm{Ry}^{2} 0.944\right)$ very well and suggests its removal is likely to be monolayeric. However, the Langmuir-Freundlich adsorption models do not fit the data as well as the Langmuir equation does.

Adsorption kinetics parameters and statistical parameters of all isotherms tested for RB5 removal are listed in Table S3. Toth generalized models were found to be the best fitting models for RB5 removal using both bacteria/CD-F 1 day storage at $4{ }^{\circ} \mathrm{C}\left(\mathrm{Ry}^{2}\right.$ 
0.977) and 7 day storage at $4{ }^{\circ} \mathrm{C}\left(\mathrm{Ry}^{2}\right.$ 0.999). The highest correlations observed in Toth isotherm suggests its removal is rather heterogenous and multilayeric by bacteria/CD-F.

\subsection{Discussion}

Electrospun nanofibers have high surface area and porous structure compare to film based materials, so, such nanofibrous materials provides better performance and higher efficiency. Moreover, during the electrospinning process, the additives such as drugs, food additives and microorganisms can be more homogenously distributed through the fiber matrix. On the other hand, the electrical power applied during the electrospinning can have some side effects especially on living microorganisms. This problem might be tolerated by increasing the number of living cells in the electrospinning solution prior to electrospinning, such that, sufficient amount of viable cells could be achieved even after the electrospinning process.

In this study, CD-F serves as an extra carbon source which promotes the growth rate of bacteria, so the utilization of freestanding CD-F based fibrous materials as encapsulation matrix is an attractive approach for the later on use of these microorganisms. However, CD cannot form a film structure and resulted in a powder material after drying of its solution without any encapsulation of bacteria which can create challenges during the practical applications. On the contrary, CD-F nanofibrous mat can be easily handled and folded as free-standing material which provides certain advantages during its practices.

As observed in the fluorescence microscopy and SEM images, even the size of bacteria is bigger than the nanofiber diameter, bacteria were dispersed pretty homogenous through the fiber matrix. Here, microorganisms were encapsulated in CD-F having different concentrations $(0.25,0.5,1$ and $2 \%(\mathrm{w} / \mathrm{w}))$ and the remediation tests were performed by using $1 \%(\mathrm{w} / \mathrm{w})$ concentrated CD-F since there were some difficulties for the electrospinning of $\mathrm{CD}$ solution containing $2 \%(\mathrm{w} / \mathrm{w})$ of bacteria. Nevertheless, as it can be observed from the results of removal tests, contaminants were remediated by high efficiency from their liquid environment $(70 \pm 0.2 \%, 58 \pm 1.4 \%$ and $82 \pm 0.8 \%$ for $30 \mathrm{mg} \mathrm{L}^{-1}$ concentrated solutions of the $\mathrm{Ni}(\mathrm{II})$, $\mathrm{Cr}(\mathrm{VI})$ and Reactive Black 5, respectively). $30 \mathrm{mg} \mathrm{L}^{-1}$ concentration is already above the acceptable limits of environmental concerns. Therefore, it can be concluded that the encapsulation efficiency of $\mathrm{CD}-\mathrm{F}$ is quite well enough for the intended applications.

\section{Conclusions}

In this study, we have shown successful encapsulation of strain Lysinibacillus sp. NOSK in CD-F by using electrospinning process. The $C D$, which is a cyclic oligosaccharide obtained from starch, was used as an encapsulation matrix and a feeding source thus facilitate an easy revival of bacteria. The suitable conditions of the electrospinning process for encapsulation of bacteria and maintaining their viability were optimized. Although the \% loading of the bacteria was limited because of the difficulty of electrospinning of fibers, the observed results confirmed that significant amount of cells survived and retained biological functionality during the process even in the drastic osmotic change and electrostatic field generated during electrospinning process. Moreover, Lysinibacillus sp. NOSK remained viable within the CD-Fs for 7 days at refrigerator conditions $\left(4^{\circ} \mathrm{C}\right)$. Electrospun fiber encapsulation technology also offers significant advantages for studying the behavior of cells under confinement. Cells, either bacterial or mammalian, were found to alter their behavior in a confined environment. We believe that the bioactivity of encapsulated Lysinibacillus sp. NOSK cells remains same in the $\mathrm{CD}-\mathrm{F}$ that can allow an easy recovery of bac- terial cells during application. The obtained results suggest that the CD-F biocomposite system well suitable for potential application in $\mathrm{Ni}(\mathrm{II}), \mathrm{Cr}(\mathrm{VI})$ and Reactive dye bioremoval from wastewater systems. Therefore, electrospinning technique may represent an excellent alternative to lyophilization for the preservation of organisms for strain collections, and for applications such as wastewater treatment.

\section{Acknowledgements}

The Scientific and Technological Research Council of Turkey (TUBITAK, project \#114Y264) is acknowledged for funding the research. Dr. Uyar acknowledges The Turkish Academy of Sciences - Outstanding Young Scientists Award Program (TUBA-GEBIP) for partial funding of the research. A. Celebioglu acknowledges TUBITAK project \#113Y348 for a postdoctoral fellowship. O.F. Sarioglu acknowledges TUBITAK BIDEB (2211-C) for National Ph.D. Scholarship.

\section{Appendix A. Supplementary data}

Supplementary data associated with this article can be found, in the online version, at https://doi.org/10.1016/j.colsurfb.2017.10. 047.

\section{References}

[1] A. Kumar, B.S. Bisht, V.D. Joshi, T. Dhewa, Int. J. Environ. Stud. Sci. 1 (6) (2011) 1079 .

[2] N. Ali, A. Hameed, S. Ahmed, J. Hazard. Mater. 164 (1) (2009) 322.

[3] S. Klein, J. Kuhn, R. Avrahami, S. Tarre, M. Beliavski, Biomacromolecules 10 (7) (2009) 1751.

[4] M.L. Bruschi, M.L.C. Cardoso, M.B. Lucchesi, M.P.D. Gremião, Int. J. Pharm. 264 (1) (2003) 45

[5] T. Ishizaka, K. Endo, M.J. Koishi, Pharm. Sci. 70 (4) (1981) 358.

[6] M.C. Mauguet, J. Legrand, L. Brujes, G. Carnelle, C. Larre, Y. Popineau, J. Microencapsulation 19 (3) (2002) 377.

[7] D.T. Birnbaum, J.D. Kosmala, D.B. Henthorn, L. Brannon-Peppas, Controlled Release 65 (3) (2000) 375.

[8] T. Uyar, E. Kny, Electrospun Materials for Tissue Engineering and Biomedical Applications: Research, Design and Commercialization, Elsevier, Woodhead Publishing Series in Biomaterials, 2017 (ISBN: 9780081010228 ).

[9] M.F. Canbolat, A. Celebioglu, T. Uyar, Colloids Surf. B: Biointerfaces 115 (2014) 15.

[10] A. Fernandez, S. Torres-Giner, J.M. Lagaron, Food Hydrocolloids 23 (5) (2009) 1427.

[11] F. Kayaci, Y. Ertas, T. Uyar, J. Agric. Food. Chem. 61 (34) (2013) 8156.

[12] Z. Aytac, S.I. Kusku, E. Durgun, T. Uyar, Mater. Sci. Eng. C 63 (2016) 231.

[13] J.H. Wendorff, S. Agarwal, A. Greiner, Electrospinning: Materials, Processing, and Applications, John Wiley \& Sons, 2012

[14] S. Ramakrishna, K. Fujihara, W.E. Teo, T.C. Lim, Z. Ma, An Introduction to Electrospinning and Nanofibers, World Scientific Publishing Company, 2005.

[15] S. Agarwal, J.H. Wendorff, A. Greiner, Macromol. Rapid Commun. 31 (15) (2010) 1317.

[16] T. Uyar, R. Havelund, J. Hacaloglu, F. Besenbacher, P. Kingshott, ACS Nano 4 (9) (2010) 5121.

[17] T. Uyar, R. Havelund, Y. Nur, J. Hacaloglu, F. Besembacher, P. Kingshott, J. Membr. Sci. 332 (2004) 129.

[18] M. Botes, T. Eugene Cloete, Crit. Rev. Microbiol. 36 (1) (2010) 68.

[19] S. Ramakrishna, R. Jose, P.S. Archana, A.S. Nair, R. Balamurugan, J. Venugopal, W.E.S.J. Teo, Mater. Sci. 45 (23) (2010) 6283

[20] A. Senthamizhan, B. Balusamy, A. Celebioglu, T. Uyar, J. Mater. Chem. A 4 (2016) 2484.

[21] O.F. Sarioglu, A. Celebioglu, T. Tekinay, T. Uyar, J. Environ. Sci. Technol. 1 (8) (2016) 2057.

[22] O.F. Sarioglu, A. Celebioglu, T. Tekinay, T. Uyar, RSC Adv. 5 (124) (2015) 102750.

[23] M. Gensheimer, M. Becker, A. Brandis-Heep, J. Wendorff, R.K. Thauer, Adv. Mater 19 (18) (2007) 2480.

[24] N.O. San, A. Celebioglu, Y. Tümtaş, T. Uyar, T. Tekinay, RSC Adv. 4 (61) (2014) 32249.

[25] W. Salalha, J. Kuhn, Y. Dror, E. Zussman, Nanotechnology 17 (18) (2006) 4675.

[26] W.Y. Fung, K.H. Yuen, M.T.J. Liong, J. Agric. Food. Chem. 59 (15) (2011) 8140.

[27] Y. Liu, M.H. Rafailovich, R. Malal, D. Cohn, Proc. Natl. Acad. Sci. 106 (34) (2009) 14201.

[28] A. Vajdai, B. Szabó, K. Süvegh, R. Zelkó, G. Újhelyi, Int. J. Pharm. 429 (1) (2012) 135. 
[29] S.W. Lee, A.M. Belcher, Nano Lett. 4 (3) (2004) 387.

[30] O.F. Sarioglu, N.O.S. Keskin, A. Celebioglu, T. Tekinay, T. Uyar, Colloids Surf. B. Biointerfaces 157 (2017) 245

[31] A. Celebioglu, T. Uyar, Chem. Commun. 46 (37) (2010) 6903.

[32] A. Celebioglu, T. Uyar, Nanoscale 4 (2012) 621.

[33] A. Celebioglu, T. Uyar, J. Colloid Interface Sci. 404 (2013) 1.
[34] A. Celebioglu, T. Uyar, RSC Adv. 3 (2013) 22891.

[35] N.O. San Keskin, A. Celebioglu, O.F. Sarioglu, A.D. Ozkan, T. Uyar, T. Tekinay, RSC Adv. 5 (106) (2015) 86867

[36] E.B. Hanlon, R. Manoharan, T. Koo, K.E. Shafer, J.T. Motz, M. Fitzmaurice, Phys. Med. Biol. 45 (2) (2000) 1.

[37] T. Granato, A. Katovic, K.M. Valkaj, A. Tagarelli, G.J. Giordano, Porous Mater. 16 (2) (2009) 227. 